\title{
DISTANCE AND PRESENCE
}

\author{
BÉLA PAZÁR \\ DLA, honorary professor. Department of History of Architecture and Monument Preservation, \\ BME K II. 82, Müegyetem rkp. 3, H-1111 Budapest, Hungary. E-mail: pazar@eptort.bme.hu
}

\begin{abstract}
When are we somewhere and when are we not? When is it "here", when is "now" and when is it not? In everyday life, this question can usually have a clear answer. But we all know the state of mind - if not from elsewhere, then from school - when we are physically present somewhere, but in fact our minds are elsewhere we are in a completely different place in spirit, being busy with something else. We can barely remember what happened in the classroom, later we are left with only what caught our attention at that time, what we were really busy with at the time. One might think that in architecture it may not even be worth addressing this issue, the situation seems so clear: here is a definite place with specific geometric features and history, shaped and formed by the mysterious "genius loci", and now is our age, the present in which we live. According to the common opinion today, good architecture expresses its own age and its own time, catching the spirit of the place. However, it is enough to think only of the Gothic cathedrals to see the very partial validity of this view. In cathedrals, the purpose of the now and here is exactly to serve, display, illustrate the time and place of the not-now and not-here.
\end{abstract}

Keywords: distance, presence, present, past

Parsifal:
I scarcely tread,
yet seem already to have come far.
Gurnemanz:
You see, my son,
time here becomes space. ${ }^{1}$

When are we somewhere and when are we not? When is it "here", when is "now" and when is it not? In everyday life, this question can usually have a clear answer. Either we were in the stadium when the new world record was born or not. Either we saw and heard Peter Brook's theater then and there or not. Either we were there at the legendary first concert of Sviatoslav Richter at the Academy of Music in Budapest or not. This is the everyday reality of here and now. But we all know the state of mind - if not from elsewhere, then from school - when we are physically present somewhere, but in fact our minds are elsewhere we are in a completely different place in spirit, being busy with something else. We can barely remember what happened in the classroom, later we are left with only what caught our attention at that time, what we were really busy with at the time. To experience being here and

\footnotetext{
\# This work was supported by the National Cultural Fund of Hungary (NKA) under Grant Number $101108 / 547$.

${ }^{1}$ Richard Wagner: Parsifal. Genius Kiadás, Budapest 1923. 38. The original German text: Parsifal: Ich schreite kaum, / Doch wähn'Ich so weit. / Gurnemanz: Du siehst mein Sohn / Zum Raum wird hier die Zeit.
} 
now in the theater during the performance is an evident feeling, and we rarely think that this here and now is actually created with the help of the not-here and the notnow. One might think that in architecture it may not even be worth addressing this issue, the situation seems so clear: here is a definite place with specific geometric features and history, shaped and formed by the mysterious "genius loci", and now is our age, the present in which we live. According to the common opinion today, good architecture expresses its own age and its own time, catching the spirit of the place. However, it is enough to think only of the Gothic cathedrals to see the very partial validity of this view. In cathedrals, the purpose of the now and here is exactly to serve, display, illustrate the time and place of the not-now and not-here. Philosophy has been dealing with this problem since the beginning. This study cannot aim to provide a philosophically relevant analysis of this issue, but perhaps it is not useless to call on the help of some well-known conclusions to convey our message.

Thinking about the nature of time is contemporaneous with mankind. It has always been an unavoidable challenge to face the problem or contradiction of constant, mathematical time existing outside the perceptible world, the monotonous life provided to our senses, which irreversibly advances to passing away, and time appearing in human mind, or in other words the time lived. We all know the famous saying attributed to Heraclitus that no man ever steps in the same river twice, because the water we step in the second time is no longer the same as before, as that water is already far from us. For Plato, the image of eternity is time, which can be observed in the motion of celestial bodies, and cognition is nothing, but a recollection of time spent in the company of ideas. On the one hand, Aristotle grasped the physical nature of time in the moment without dimensions, as illustrated by the physical concept of a point which is inseparable from motion and change, on the other hand, he linked it to the nature of truth. According to St. Augustine of Hippo, time cannot be defined in the conceptual system of measurable units, because there is no limit to what short units it can be divided into, and thus its measurability is eliminated. Therefore, time cannot relate to physical movement, but to the expansion of the soul, its extensive movement, which can only have an internal measure. He says: "What then is time? If no one asks me, I know what it is. If I wish to explain it to him who asks, I do not know. " In the Middle Ages, time meant a temporary earthly existence, as opposed to the one eternal God. With the evolving practice of regular observation of nature, already in the late Middle Ages and then in the Early Modern Age (Renaissance and Baroque), actually Aristotle's natural philosophical interpretation was reborn. Newton saw time as the absolute medium of existence, Leibnitz as the relative order of successive things, while Kant, in connection with the Platonic tradition, interpreted time, together with space, as a pure form grafted into the human view. In Hegel's philosophy, "Time is the Concept itself that exists there and is represented to consciousness as empty intuition." "Thus Time appears as the very fate and necessity of Spirit when it is not in itself complete - the necessity of its giving self-consciousness a richer share in consciousness..." ${ }^{2}$ Bergson interpreted lived time in terms of duration:

\footnotetext{
${ }^{2}$ Hegel: A szellem fenomenológiája. [The Phenomenology of Spirit] Akadémiai K., Budapest 1961. 410.
} 
"Evolution implies a real persistence of the past in the present, a duration which is, as it were, a hyphen, a connecting link. In other words, to know a living being or natural system is to get at the very interval of duration, while the knowledge of an artificial or mathematical system applies only to the extremity." "The duration of the Universe, then, certainly coincides with the abundance of creation in it."3

A daily experience is that spaces and masses can only be perceived in time. We are moving in space, around the different masses. This is the case even for interior or exterior architectural spaces and masses composed to one point of view, since what we see from a privileged point of view must be distinguishable from what we have seen before or after. Relocation, movement - or in a borderline case, its extreme value, i.e. the state of physical rest - and short-term personal memory are elementary conditions for perceiving architecture. This process consists of the senses of sight, touch, and the work of memory that stores, organizes, activates, and combines these perceptions. Buildings, spaces, and places that exist longer than our finite lives have already belonged to the lives of our ancestors and over time will become part of the lives of our descendants, connect the domains of personal memories, create our common memory, ensure the continuity of our environment and create our sense of home. Thus, they are shapers of our personal and community identity. The German term Erinnerung, which literally means becoming internal, acquiring something illustrates the content and significance of this process. Extension can be considered a defining property of space. Actually, the point without extent can be interpreted as a denial of space. If, according to natural philosophy, time is considered to be an infinite series of innumerable Now-s without expansions, then time must be regarded as a denial of space. Thus, the exclusive Now is the extent- or space-free topicality. On the other hand, in geometry, the point can be determined only by means of two intersecting lines, i.e. only with the help of two other points, so the definition and identification of "here" can only be done with the help of distance and extent that is "not here". In the middle of the endless ocean, where there is no terrestrial "not-here", we can only determine our position with the help of celestial bodies. The "here" only becomes a reality when contemplated from the position of the "not-here", that is, in the extent or in the space. If we said before that time is a denial of space, then we can now say that the concept of time is the extent and space itself. Not only in a geometric, but also in an intellectual and spiritual sense. ${ }^{4}$ In connection with this European philosophical tradition, Lajos Fülep also pointed out the role of memory in artistic work and distinguished between practical and artistic vision. In ordinary, practical vision, memory dissolves into perception. We perceive the surrounding world in order to remember. The purpose of our vision is to understand the meaning of what we have just seen with the help of our memory, and to be able to act correctly by using this knowledge. A clear example of this vision is the driver's vision. He needs to remem-

\footnotetext{
${ }^{3}$ Henri Bergson: Teremtö fejlödés. [Creative Evolution]. MTA, Budapest 1930. Reprint, Akadémiai K., Budapest 1987. 26, 308.

${ }^{4}$ In Chapter 6, Heidegger analyzes at length the interpretation of time in the philosophical tradition. Martin Heidegger: Lét és Idő [Existence and Time]. Gondolat, Budapest 1989. Chapter 6. from 643.
} 
ber exactly what he learned about the signs of the traffic rules and needs to know what the perceived sight instructs him with unconditional validity. In artistic vision, by contrast, perception dissolves in memory, and remembrance is not for vision and direct action. Everything happens the other way round here, our memory determines what we are sensitive to, what we perceive and notice at all. We remember in order to perceive. Fülep called this vision, free from the compulsion to follow each other, the View. ${ }^{5}$ A few years later, Erwin Panofsky formulated a similar opinion: "To grasp reality we have to detach ourselves from the present." 6

A few years ago, at an exhibition, Hungarian architect Rudolf Klein presented the works of the Japanese Tadao Ando, with a method developed in Europe, i.e. the technique of photography, which captures the image using a chemical process. These photographs, like the building photos by Lucien Hervé or Hans Danuser, did not simply praise the expertise of the professional master. The images showed something that went beyond the way of representation and often even the object of the representation itself. They made me think, took me with them, on a long journey to distant landscapes and distant times. Sometimes I even had to close my eyes for a moment so that the current stimuli of the outside world would not disturb the inner "reverberation" of the given image. With my eyes closed, I was not thinking about Ando's buildings. I felt his architectural program and method too direct and obvious even from a distance. His famous cross standing in the water always gave me the impression of the fatally misunderstood interpretation of the cross in the woods behind the glass wall of the beautiful chapel of the University of Otaniemi. Looking at the photos of the exhibition, I was just wondering where the complex interplay of vision "extended" by the techniques of representation, memory and view draws the line between eclectic selection and synthesis, a relentlessly strict boundary barely noticeable at first, but becoming crystal-clear over time.

Man is one of the living beings. His vision is far from the best in the living world. But during a person's life the ability develops to show what he sees to those who do not see it. Also, there are sentinels in the wildlife who warn their peers of the danger. These animals signal to others with movement and sounds what they are already perceiving, but the others are not yet. This direct form of communication still exists in human communities to this day, but an infinitely rich system of indirect communication has also been created. In this system, people record the experience in a mutually agreed sign system, being imprinted in some material, store it for a longer or shorter period of time and transmit it on a material data carrier. The first great seers and presenters were the fortune tellers and shamans, the chosen ones who kept in touch with the fearsome, unknowable superhuman powers, and reported the others

\footnotetext{
${ }^{5}$ Lajos Fülep: Az emlékezés a művészi alkotásban. [Remembering in the Work of Art] In: L. Fülep: A müvészet forradalmától a nagy forradalomig. Cikkek, tanulmányok. [From the Revolution of Art to the Great Revolution. Articles, Studies] Magvető, Budapest 1974. 644.

${ }^{6}$ Erwin Panofsky: A mủvészettörténet, mint humanista tudomány [Art History as a Humanistic Science]. In: E. Panofsky. A jelentés a vizuális müvészetekben [Meaning in the Visual Arts]. Gondolat, Budapest 1984. 277.
} 
on higher decisions. Depiction is our ancient representational activity that has helped us create community depiction and vision, and different cultures of depiction and vision. The way I see it, the way you see it, the way he sees it. Different civilizations have different histories and cultures of representation and vision.

The technique of photography was probably created in Europe because European thinking and vision formulated the laws of optics and developed the technique of perspective projection - to project a sight on a plane sometime in the $15^{\text {th }}$ century and the concept of the vanishing point in infinity. The depth of the space has already been captured by Greek and Roman depictions, Vitruvius also wrote about perspective pictures prepared for the Greek stage, while Roman architectonic murals are known from Pompeii. The tradition of Antique representation was revived at the end of the Middle Ages when its precise measurement rules were formulated. This technique first developed in Italy and the Netherlands (Low Countries), defined European vision and thinking for centuries. After the centuries long period of the continuously evolving mechanical image-reproduction techniques, the complex work of the eye, hand, and brain creating the picture suddenly lost its significance as the image was formed in seconds, later in tenths of a second, by the chemical reaction of some substances. Then, another hundred and fifty years after the creation of the first daguerreotypes, followed by the golden age of photography and film - now inseparable from modern art of the $20^{\text {th }}$ century - a new technique, namely electronics has replaced the chemical mechanism of imaging. The image is now created at the speed of light, in any quantity, its physical value is disappearing. Today we use the digital technique of representation in all areas of life, from illustrating microbiological processes or the structure of the universe to the virtual reconstruction of destroyed buildings. With this technique, we can observe what we cannot yet see, can no longer see, or have never been able to see with our eyes. Virtual reality, the illusion of a moving and audible reality is an unparalleled and novel experience, but it can also short-circuit our inner vision. The technique of depicting spatial shortening replaces reality with appearance. Perspective, the technique of depiction improved in Europe, also became common in cultures outside Europe in the $20^{\text {th }}$ century with the spread of photography, and by the end of the century, digital visual design and visualization tools made the domination of virtual and perspective representation total. The Mongeian axonometric representation, which is related to non-European representational techniques and presents real dimensions - being widespread in $20^{\text {th }}$ century Modern architectural representations and becoming a symbol of the abstract Modernhas almost completely disappeared, and gave way to traditional, perspective-based visual designs made with digital technology. The liberating effect of different cultures of vision and representation mixed in twentieth-century art can now only be felt in museums.

The technique of perspective representation developed in Europe is tied to a specific point of view. The sight is projected from a single place, without moving, to the plane in front of us, on an ideally transparent surface stretched on a frame delimiting the view. This projection always shows a delimited space defined by the cut-out of 
the image field similar to the view seen from the window. This is so even if the image field that closes the space from above depicts the sky and clouds. A space delimited and cut out of nature is called an architectural space. Therefore, irrespective of their theme, European perspective representations always depict an architectural space as well. The perception of natural and architectural space is not only the work of sight, but also of touch and movement. We walk around the space. Sight itself is inextricably linked to the direct perception of physical qualities in which all our senses are involved. These sensations are turned into the process of vision by the movement of our body and the memory mechanism of our brain.

The man-made world, the representation of architecture has always been an important tool in the traditions and techniques of representation. Buildings and architectural elements form an exterior or interior space in the pictures, serving as foreground, background, venue, or part of a natural landscape. We see and recognize many of their physical qualities, different times, places, and people meet in the specific space and time of representation. European painters often depicted mythological or biblical scenes as if the event grasped had taken place in their own age. They identified with the characters in the stories, felt and lived their destiny, having the impression that these characters all belonged to the creators' own age. Prior to general spread of writing and reading, the image was a necessary tool of human communication, and in many places, it is still considered indispensable in the various forms of calligraphic or pictorial writing. How irresistible the direct power of the image can be, we still experience every day, and see it in the often frightening, depressing and literally captivating effect of advertising.

Prior to the generalized experience of modern space enclosed in the image field, space was our unconscious, everyday human experience. The method of modern perspective representation is a few hundred years old, while today's concept of architectural space developed much later, after the concept of physical space was born in Europe. In his famous study "Perspective as Symbolic Form", Panofsky presented the stages of the development of the modern European perspective and the significance of this process. ${ }^{7}$ He writes that the decisive turn, the step forward took place when artists were able to determine precisely the distances perpendicular to the image plane. This required someone who not only took the pictures, but also drew a section for his work, in which he also had to specify the depth dimensions in relation to the image plane, and thus be able to represent the point of view from the side. This made it possible to clearly determine the dimensions and position of the objects in the perspective image, i.e. to map them in a uniform system and thus see them in a uniform space. This system space is the modern three-dimensional space mathematically formulated later by Descartes. For centuries, for the ancient Mediterranean man, and then for the medieval European man, the universe was a central architectural space imagined by the experience of the sky seen from the earth, with a center

\footnotetext{
${ }^{7}$ Erwin Panofsky: A perspektíva, mint szimbolikus forma. [Perspective as Symbolic Form] In: E. Panofsky: A jelentés a vizuális müvészetekben [Meaning in the Visual Arts]. Gondolat, Budapest 1984. 170-248.
} 
or centers, peripheries, and other defined spatial relationships. This is the empirical geometric worldview of Aristotle. In the early centuries of Christianity, space was amorphous, the spiritual light itself, depicted with a golden field filling the picture. Dante, who was active at the end of the Middle Ages, described geometric spaces again. He gave an accurate, illustrative description of the places of his journey, the topography of the landscapes of the afterlife. In addition to the development of the technique of perspective representation, the European concept of space was also shaped and enriched by the abstraction work - used essentially for positioning - of sailors, later land surveyors and mappers who orient themselves with the help of the sky, and by long-term movement, distance vision discovering and organizing the sky, in other words the ability to make things seen that are invisible to the naked eye. One of this work's most important tools, the optical instrument for distance vision, was the telescope. The worldviews of Copernicus, Galileo, Kepler, and Newton abolished the absolute nature of the Earth as a place of geometric reference point. The European man was then able to look at himself in the space from the outside, seeing himself be inside and outside at the same time. The miracle of creation has now become an infinite space that can be clearly described, represented and learned with the tools of geometry. This infinite space is the Universe of which we earthly beings are only tiny parts. This concept of the outer and the inner, the finite and the infinite belonging together in one space did not develop in the worldview and representational traditions of cultures outside Europe, where the finite and the infinite, something and nothing have not become part of the measurable, definable world.

After the heyday of ancient Mesopotamian river cultures, before the emergence of the modern geographical concepts of Asia, North Africa, and Europe, these continents' shores along the Mediterranean formed a maritime inter-land unit, which had a natural connection to the continental East. The concept of the far away, the distant meant those eastern lands, regions, countries and folks inaccessible or unreachable to ordinary people.

After the disintegration of the Antique world and the early medieval Mediterranean cultures, and then in the centuries of the rise of the Ottoman Empire and the division of the Mediterranean, the attraction of the East drove the brave European sailors on their way to sea. The ongoing process of meeting and interacting between human cultures living in isolation on different continents was started by Europeans who travelled and came to know the world at the end of the Middle Ages. In parallel with the mapping of the Earth, learning about Chinese, Indian, Islamic and then Japanese culture became an increasingly active shaping force in Europe in the $18^{\text {th }}$ and then in the $19^{\text {th }}$ century. By the second half of the $19^{\text {th }}$ and $20^{\text {th }}$ centuries, this encounter became regular, mutual, and universal. And this has become one of the hoped-for means of overcoming the ancient Christian formal heritage, which was often felt depressive due to the accumulated and systematized historical knowledge, and in many cases the tools of articulating national, religious identity. The almost obligatory element of the $18^{\text {th }}$ century landscape, i.e. the Chinese, sometimes the Indian pavilion, or furniture with pearl, shell and ivory inlay and Rococo Chinese lacquering technique, 
porcelain ornaments and interiors were still special accessories of aristocratic luxury. The world exhibitions of the next century, which showcased the technical achievements and - in the wake of a comprehensive, worldwide, scientific, and cultural collection - presented civilizations outside Europe have already been visited by a large number of people. These events are still considered to be significant stages in the history of architecture and the entire universal culture. At the turn of the century, and then in the first years of the $20^{\text {th }}$ century, Eastern orientation was one of the defining elements in European architecture, applied arts, fine arts, and music. The Far East, especially Japan, being opened after hundreds of years of isolation, gradually became a direct neighbor of the West from the Pacific Ocean. The experience of the East reached America without European mediation. The 1893 Chicago World's Fair marked a turning point in Frank Lloyd Wright's architecture. On the one hand, this exhibition was a victory of commercial pragmatism (i.e. gypsum stuccos dressing iron structures in historical costumes) over the forward-looking results of the Chicago School - Louis Henry Sullivan judged that the exhibition would set back Chicago's architecture for decades. On the other hand, similar to the experience of the 1851 London World's Fair, which also had a great influence on Gottfried Semper, learning about the objects of old Japanese and Mexican culture had a liberating effect on innovative American aspirations. The Japanese government has built a copy of Ho-oden Temple and a Japanese tea house to showcase the country's culture. As a result of this experience, Frank Lloyd Wright, who, along with his contemporaries, explored the possibilities of creating true American-rooted architecture beyond the hierarchical European architectural traditions, began to study Japanese and then Mayan, Aztec, Totlec Mexican architecture, and later started to collect colorful Japanese woodcuts. ${ }^{8}$ Tokonoma, the central element of the interior of the Japanese house, is a place of intimate contemplation. Wright's intertwined, freely designed, flowing spaces, breaking with symmetry, were organized around the fireplace as a central element, coming from Europe. The Japanese influence was an important moment on the road to the formation of his elongated, horizontal "prairie" houses covered with low-sloping hip roofs with deeply projecting eaves. In addition to Japanese inspiration, the traditional, free-form construction of the English country house, which became widely known and popular at the time, also prevailed in Wright's buildings, as before in the spirit of Arts and Crafts in England, or in the works of Webb, Voysey, and later Mackintosh. For the first time, the architectural culture of East - primarily Japan and West was so closely intertwined in Wright's early architecture, in America, and from then on visible in some places and appearing in a hidden way in other places, but this interaction is continuous in the architecture of the $20^{\text {th }}$ century. Wright then designed in Japan as well, but the Hotel Imperial, which was built in Tokyo between

\footnotetext{
${ }^{8}$ The large-scale exhibition Weltkulturen und Moderne Kunst held in Munich in 1972 presented the centuries-old process of European cultures based on the anti-Christian tradition meeting non-European cultures. The study of Wolfgang Pehnt: Der Orient und die Architektur des 19. und 20. Jahrhunderts discusses this process in detail. See also ibid. Manfred Schneckenberger: Frank Lloyd Wright und die präkolumbische Architektur. Weltkulturen und moderne Kunst. Verlag Bruckmann, München 1972. 47-52, 520-524.
} 
1915 and 1917 and later destroyed by an earthquake, primarily does not show Japanese style, but the influence of pre-Columbian Mexican architecture typical before the Spanish conquest.

At the turn of the $19^{\text {th }}$ and $20^{\text {th }}$ centuries, and then in the first decade of the century, Wright's buildings and modern American architecture were already known in Europe. Under the influence of Wright's architecture, Japanese inspiration sometimes indirectly affected the Old World. Many scientists, artists, and architects traveled to America to try their luck there, or just to get to know the New World. Usually, no direct Eastern influence is mentioned in connection with Adolf Loos' buildings. Apart from a few details, it is not really the oriental motifs that dominate his houses. Yet, "Raumplan", Loos' concept of space, which critically rejects the additive compositional tradition of spaces enclosed in themselves, undoubtedly bears a resemblance to traditional Japanese spatial design. The latter is broken down almost into the smallest moments of life, forms a chain of intertwined external and internal spaces that provide a framework for different activities in the human home. Loos saw the house, the apartment, the interiors such an integral part of the identity of the personality as dressing. Similarly to modern clothing that is appropriate for the occasion, low-key and unobtrusive, the building should not be loudly extravagant, but practical and restrainedly elegant. Loos did not consider decoration a superfluous gesture when it was non-self-serving, healthy-scale resulting from the material and the method of processing, representing the constructive thinking and skill of the master builder, who is proficient in his business, and expressing his joy, but found it a natural and important part of the builder's craft, work, and life. But he rejected the use of the natural ornaments of the past, which have become empty and deprecated into cheap mass item during industrial series production. Loos' position, willingly or unwillingly, is close to the tradition of Japanese architecture and handicrafts, different from the European one, being less individual, more abstract and more geometric, still preserving the properties of material and the finesse and direct power of the work of the human hand. This similarity is particularly striking in the interiors of the Loos buildings. Just like the Viennese architects at the turn of the century, Loos' approach was greatly influenced by the work of Gottfried Semper. But when talking about this effect, one must not forget that Semper's influential line of thought, 'Bekleidungstheorie' - the 'theory of dressing' - was born right out of the experience of learning about cultures outside Europe. ${ }^{9}$

In the years following the Art Nouveau and then the First World War, the interest of European architects in Eastern culture did not diminish. After his trip to the United States in 1911 and East India in 1923, Hendrik Petrus Berlage designed his late masterpiece in 1927, the Gemeindemuseum in The Hague, a building completed in 1935, a year after his death. The intertwined masses unfolding behind the sparkling water surfaces, the covered road starting from between the two obelisks, crossing the water

\footnotetext{
${ }^{9}$ Gottfried Semper's theory is often referred. In my opinion, if we want to stay true to Semper's spirit, technical necessity and meaning cannot be separated and contrasted when interpreting "Bekleidung".
} 
and leading to the entrance, the fabric of the interiors tailored to the needs of each collection, being freely connected with fine split levels, but also Berlage's furniture and often his drawing style capture the great experience of the encounter of East and West. Bruno Taut spent a long time in Japan, and Elieen Gray herself mastered oriental lacquering techniques. Her furniture simultaneously evokes uniquely Modern, Antique and Oriental reminiscences. Decoration in the traditional sense, the decorative art that can easily be interpreted by the wider public and follows the centuries-old natural depiction, lived on a bit longer in Europe and America in the "Art Deco" style. This trend preferred using exotic elements, this way passing on and reviving previous oriental influences, the various techniques of inlaying, lacquering and metallization. In the ensuing 1930s, however, the natural and figurative decorative tradition became a manipulative tool for various imperial representations and a stage prop for the entertainment industry. The activist and productivist Modern movements, unfolding in Europe at the beginning of the century, aimed for the renewal of all areas of life with an overwhelming momentum. Gestures of the East, preserving handicraft traditions and sometimes being imperceptibly subtle and restrained for the average European or American, have been out of sight of European avant-garde movements for a time, at least on the surface, in watchwords, proclamations and catechisms. Artists, theorists and artistic trends of the age gladly referred to the theory of relativity formulated in physics at the beginning of the century, which stated that space and time, each of which had hitherto been considered absolute, were not independent of each other. About a hundred years ago, artists thought of discovering the coherent artistic equivalent of the scientific worldview in the stylizing techniques of Futurism and Cubism simultaneously depicting the phases of movement and snapshots taken from different views just as in the previously unknown, truly novel pictorial experience of photography and film. While the latter were indeed inextricably linked to the novelties of technology, the creation of the former was decisively contributed by the rediscovery of the ancient, multi-point-of-view representations, so the work of memory and tradition. But the independence of space and time in physics disappears only in systems that move rapidly, at the speed of light, in the realm of elementary particles, and in the world of gravity in cosmic space. Under our earthly conditions, space and time can still be described by the laws of Newtonian mechanics, which prevail in the Euclidean space accessible to our senses, a space unchanged in this sense. Yet, the experience of constant movement, change, uncertainty, temporality, light, moment, speed is unilaterally and somewhat anachronistically linked again and again to development, novelty, progress, or, a little vulgarly speaking, to modernity. Yet electronics, the world of signals moving at the speed of light, features a motion no longer perceptible for us, but a simultaneity in which perceptible movement (i.e. physical change or the symbol of modernity) disappears into nothingness. When we think today that only the things belong to our age that truly express and mediate these experiences and states, which represent and convey change, then we forget that we are following a tradition that is more than a hundred years old, operating according to the pattern of $19^{\text {th }}$ century Historicism rejected by 
modern thinking in the $20^{\text {th }}$ century, in which no new elements are left by now. The close connection of the Modern with the preceding ages was not conspicuous for a long time. Under the influence of avant-garde proclamations and catechisms of the last century, we still tend to identify it simply on the basis of morphological criteria. As if the history of architecture is a morphological competition that lasts until the end of time according to the model of the history of style.

The new ideal, modern technical art proclaimed strictly abstract design principles. But if after reading the proclamations, the created material is studied closer, it is hardly deniable today that the representatives of the formative aspirations that thought and called themselves functionalists - in addition and often instead of following the functional considerations that truly emerge in admired and many times fetishized industrial forms - were inspired (perhaps not always consciously) by the centuries-old abstract compositional tradition of non-European cultures, especially the craft world of the East. In the dominant workshops of the Modern movement, samples of products intended for industrial series production were made with the highest level of craftsmanship, and in the age of aircraft and radio, apprentices were raised in these workshops to the noblest craft tradition. The aim of the early Modern was to remedy and humanize the alienating effect of industrial mass production, and to this end it turned to the tradition of the handicraft industry. The movement proclaimed that beautiful and true forms are created by good artists. After the artistic endeavors of the craft movements, the modern avant-garde of the $20^{\text {th }}$ century no longer celebrated the forms of the craft tradition, but was enthusiastic about the machines of the factory industry condemned by the predecessors, and proclaimed with unclouded optimism that the machine was an obedient servant of man. However, the machine will only perform the operation many times that the craftsman or artist's hand has already done before. The human and intellectual performance of industrial production, series production and standardization seem to be quite different from the human performance of the craft tradition. At the time of its construction, Mies van der Rohe's exhibition pavilion in Barcelona, built in 1929, seemed to articulate this distinction with complete consistency. But were the bricks, the stone drums making up the classic column, the column order and its elements, the design rules of the vault, the sizing of country houses, or the adobe technique not permanent, "mandatory standards" applied for centuries or thousands of years, many of which we still use, or in fact, reuse even today? Can we consider the use of iron, steel, chrome, concrete or glass as a "watershed" merely because of their material reality, as seen in the heroic age of Modern architecture? With the here and now vanishing, the materials, stone, steel, glass, water, have disappeared from their own reality. But even in the absence of material presence, the irresistible attraction of some mysterious not-here and not-now forced the rebuilding of the pavilion decades later. This not-here and not now-has come to life again. The silent and lean majesty of the columned Antique temple, the closed and open intimacy of the Japanese house, which opens to the processed exterior cut out of nature, the living surface of Mediterranean travertine stone, the ultramodern luxurious luster of chrome steel, the enigmatic space-desig- 
nating effect of glass, the friendly and comforting pebbles formed by the millions of years of water work are here and now together, at the same time, present.

The building lacks concrete morphological references, does not illustrate anything, does not mean anything, but displays or represents in a deeper sense of mimesis. ${ }^{10}$ How aware of this Mies was, who turned away from both the past and the utopia with consistent rigor and was pragmatic in his statements, is no longer relevant. The common belief mentioned in the introduction needs to be reviewed at several levels: whether good architecture can express the here and now only if it is also a share in what is not here and now. ${ }^{11}$

Mies's pavilion in 1929 seemed to justify the expectation widespread by the beginning of the $20^{\text {th }}$ century that the means of modern industrial production would radically renew architecture as well. After the exhibition, its magical memory gradually became one of the defining role models of modern architecture, and with increasing cultic force, it influenced Modernism, which unfolded freely, especially in the post-World War II period. After 1986, the rebuilt pavilion then became a cult site itself. By the time of the 1989 political turn in Europe, the cult was enriched with some important elements: the rebuilt pavilion has become a symbol of progressive science and culture, democracy and a responsible European historical engagement for a reborn democratic Spain and then a reunited Germany. This message is also expressed in the most prestigious European architectural prize, which rewards outstanding achievements in contemporary European architecture and is presented in the pavilion. The practice of rebuilding was previously fundamentally foreign and unacceptable to modern architectural thinking of the $20^{\text {th }}$ century. The only exception was the reconstruction of buildings and complexes of outstanding universal or national cultural value that were destroyed in World War II, but they were seen not so much as architecture, but rather as a respectable but architecturally uninteresting value-saving work by specialists. The reconstruction of the pavilion in Barcelona has changed this situation. Modern, which always defines itself with unconditional progress and wants to break away from all kinds of past, now symbolizes itself with a modern building rebuilt from the past. Thus architecture, contrary to Mies's formulation, is perhaps not merely a manifestation of the will of a time, a place, an age, but an answer to a question of how people lived, live and will live, from time to time in a place. For the benefit of not one man, not a few people, but of humanity. This is the human perspective of time, a human responsibility, as Jacques Derrida put it: "If the

\footnotetext{
${ }^{10}$ In his study Vom Sinn der Mimesis, Wladimir Weidlé analyzed the original meaning of mimesis and the formation of layers of meaning that obscure it over time, based on the research results of $19^{\text {th }}$ century German classical philology. The word was originally related to the performance of cult dances, it was not primarily an imitation but a representation. Weidlé illustrated the difference with the terms 'bezeichnen' (to describe) and 'darstellen' (to depict). The literal Hungarian translation of 'darstellen' is much more sensitive than the word 'to represent': "elö-állít" (=prepare), or "elö-ad" (=perform) in this sense, here and now. Wladimir Weidlé: Gestalt und Sprache des Kunstwerks. Mäander Kunstverlag, Mittenwald 1981. 41-56.

${ }^{11}$ Hans Georg Gadamer uses this term several times in connection with the problem of progress and understanding as receiving.
} 
living present does not have this non-simultaneity with itself, if there is nothing that secretly breaks it down, if we do not have this responsibility and love of justice for those who are not there, who are no longer or have not yet been present as living beings, then what is the point of asking the question: where are we going today?, where are we going tomorrow?"12

\section{TÁVOLSÁG ÉS JELENLÉT}

\section{Összefoglaló}

Mikor vagyunk valahol, és mikor nem? Mikor van itt, mikor van most és mikor nem? A mindennapi életben e kérdésre általában egyértelmúen válaszolunk. De mindnyájan ismerjük azt a lelkiállapotot - ha máshonnan nem, hát az iskolából -, amikor fizikailag valahol vagyunk, de valójában egészen máson jár az eszünk, lélekben egészen máshol vagyunk, mással vagyunk elfoglalva. Alig emlékszünk arra, hogy mi történt ott akkor az órán, később csak az marad meg bennünk, ami akkor figyelmünket lekötötte, ami akkor valójában foglalkoztatott. Azt gondolhatnánk, hogy az építészetben talán nem is érdemes foglalkozni ezzel a kérdéssel, olyan egyértelműnek látszik a helyzet: az itt, egy meghatározott hely sajátos geometriai tulajdonságokkal és történelemmel, amelyet a titokzatos „genius loci” alakít, formál, a most pedig a mi korunk, a jelen, amelyben élünk. Mai általánosan elterjedt vélekedésünk szerint a jó építészet a hely szellemét megérezve saját korát, saját idejét fejezi ki. Elég azonban csupán a gótikus katedrálisokra gondolnunk ahhoz, hogy belássuk e vélekedés nagyon is részleges érvényességét. A katedrálisokban a most és itt célja éppenséggel a nem most és a nem itt idejének és helyének szolgálata, megjelenítése, szemléltetése.

Kulcsszavak: távolság, jelenlét, jelen, múlt

${ }^{12}$ Conversation with Jacques Derrida. Magyar Nemzet (30/10/2004), published by Lajos Boros.

Open Access statement. This is an open-access article distributed under the terms of the Creative Commons Attribution 4.0 International License (https://creativecommons.org/licenses/by/4.0/), which permits unrestricted use, distribution, and reproduction in any medium, provided the original author and source are credited, a link to the CC License is provided, and changes - if any - are indicated. (SID_1)

Received: 14 May 2020. Accepted: 16 May 2020

First published online: 13 October 2020 